\section{Exhalation rate of radon-222 from concrete and cement mortar}

\author{
Allan Felipe Nunes Perna, \\ Sergei Anatolyevich Paschuk, \\ Janine Nicolosi Corrêa, \\ Danielle Cristine Narloch, \\ Rafael Carvalho Barreto, \\ Flávia Del Claro, \\ Valeriy Denyak
}

\begin{abstract}
The main sources of radon in the air of dwellings are soil, building materials, and groundwater. This study aimed to determine the exhalation rate of ${ }^{222} \mathrm{Rn}$ from samples made of concrete and cement mortars, as well as to evaluate by means of gamma spectrometry the hazard indexes associated with other radionuclides present in the studied samples of building materials. The results obtained allowed the comparison of the exhalation rate of radon using theoretical calculations based on one-dimensional and three-dimensional models. Measurements of the activity concentration of radon in air was performed by AlphaGuard radon detector. Furthermore, obtained results were compared with the measurements performed inside the concrete test cells. These test cells were built with the aim of simulating a dwelling in small dimensions and to evaluate indoor radon activity associated with concrete. Consequently, the obtained results of radon exhalation rate, in becquerel per meter squared per hour, for the concrete was $2.55 \pm 0.03 \mathrm{~Bq} \cdot \mathrm{h}^{-1} \cdot \mathrm{m}^{-2}$ for the $1 \mathrm{D}$ model and $0.461 \pm 0.008 \mathrm{~Bq} \cdot \mathrm{h}^{-1} \cdot \mathrm{m}^{-2}$ for the 3D model. The exhalation rate of radon, for the cement mortar was $1.58 \pm 0.03 \mathrm{~Bq} \cdot \mathrm{h}^{-1} \cdot \mathrm{m}^{-2}$ for the $1 \mathrm{D}$ model and $0.439 \pm 0.011 \mathrm{~Bq} \cdot \mathrm{h}^{-1} \cdot \mathrm{m}^{-2}$ for the 3D model. The indoor concentration of ${ }^{222} \mathrm{Rn}$ from the test cell was $112 \pm$ $9 \mathrm{~Bq} / \mathrm{m}^{3}$. These values were below the limit of $300 \mathrm{~Bq} / \mathrm{m}^{3}$ recommended by the International Commission on Radiological Protection (ICRP) and $<148 \mathrm{~Bq} / \mathrm{m}^{3}$, the limit recommended by the US Environmental Protection Agency (US EPA). Even so, these values should be the subject of concern since that activity is related only to the contribution of concrete walls.
\end{abstract}

Keywords: cement mortar $\bullet$ concrete $\bullet$ exhalation rate $\bullet$ radon-222

\author{
A. F. N. Perna, S. A. Paschuk, J. N. Corrêa, \\ D. C. Narloch ${ }^{\bowtie}$, R. C. Barreto, F. Del Claro \\ Federal University of Technology - Paraná, UTFPR \\ Av. Sete de Setembro, 3165, Curitiba - PR \\ CEP 80230-90, Brazil \\ E-mail: daninarloch@hotmail.com

\section{Denyak} \\ Pelé Pequeno Príncipe Research Institute \\ Av. Silva Jardim, 1632, Curitiba - PR \\ CEP 80250-060, Brazil
}

Received: 15 November 2017

Accepted: 15 May 2018

\section{Introduction}

Radon $\left({ }^{222} \mathrm{Rn}\right)$ is a naturally radioactive gas, the principal sources of which within dwellings are soil, building materials, and groundwater. Radon is derived from the decay of isotopes from uranium and thorium chains, and the biggest concern is related to the isotope ${ }^{222} \mathrm{Rn}$, whose half-life of 3.8 days makes it possible for this gas to migrate from the soil, water, fossil fuels, and construction materials into the atmosphere of dwellings, where it mixes with air and can be inhaled by humans. Undergoing alpha decay and producing long chain of alpha-particle- and beta-particle-emitting progeny radon could cause lung cancer [1-3]. Moreover, radon and its progeny are responsible for more than half of the annual dose received by the population from natural ionizing radiation [4].

Naturally, a very high activity of radon in air could be found in the ground floor environments, where the soil is considered as the main source of radon concentration [5]. However, in the case of low- and mid-rise houses, radon activity could 
be detected in the air of upper floors with poor ventilation and is related to naturally radioactive raw substances used in building materials $[6,7]$.

Considering that the quantity of radon exhaled by construction materials is mainly determined by the radium content, many efforts have been made to study the correlation between radium activity in building materials and radon activity in air. For example, according to a previously published review [8], which used a model of a typical house with indoor volume of $375 \mathrm{~m}^{3}$ with a floor concrete slab of $10 \mathrm{~cm}$ thickness and masonry walls of area $150 \mathrm{~m}^{2}$ with typical radium concentration of $40 \mathrm{~Bq} / \mathrm{kg}$, the radium content in those building materials could probably contribute to radon activity in air between 0.006 and $0.56 \mathrm{~Bq} / \mathrm{s} \mathrm{[8]}$.

The present work discusses the results of measurements of ${ }^{222} \mathrm{Rn}$ exhalation rate from concrete and cement mortars, as well as the characterization of radionuclides present in these materials. Obtained data were analysed using theoretical calculations based on one-dimensional (1D) and three-dimensional (3D) models for radon exhalation. These building materials were selected because of their vast usage in diverse masonry constructions, such as houses and buildings, as well as underground constructions such as garages, shelters, and subways, among others.

\section{Materials and methods}

The exhalation rate of radon from building materials was evaluated by continuous measurements of ${ }^{222} \mathrm{Rn}$ activity in air, using sealed glass containers with inserted samples of selected materials. Furthermore, the samples of concrete and cement mortar were characterized by gamma spectrometry analysis with the aim of obtaining ${ }^{226} \mathrm{Ra}$ concentration, which is the radioactive precursor and the source of radon. In the last step, the test cell was manufactured using the selected concrete and cement mortars to simulate the indoor environment of a dwelling. ${ }^{222} \mathrm{Rn}$ activity in the internal air of the test cell was measured using CR-39 track etch detectors installed inside diffusion chambers, as described by Perna [9]. In this way, the calculated values of radon exhalation rate from the sample of concrete and cement mortars were compared with obtained values of indoor activity within internal volume of the test cell.

\section{Manufacturing of samples of building materials and construction of the test cell}

In order to perform the measurements of exhaled radon from concrete and cement mortars, cylindrical samples of these materials of $5 \mathrm{~cm}$ diameter and $10 \mathrm{~cm}$ height were molded. The samples were prepared at the Federal University of Technology - Paraná (UTFPR), following the protocol established by Brazilian Association of Technical Norms (NBR NM 67: 2012; NBR 7215: 1996) [10,11], as described by Perna [9]. After manufacturing, the

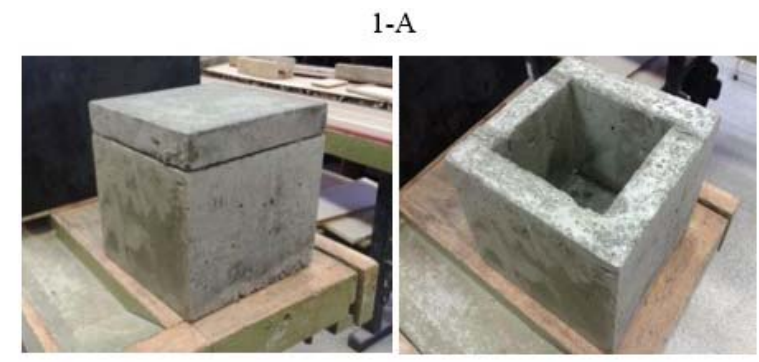

$1-B$
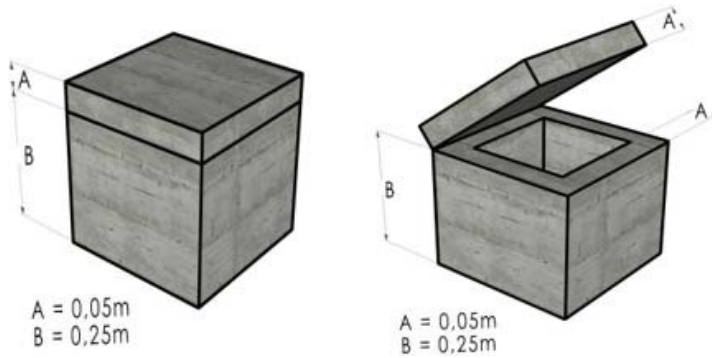

Fig. 1. General view of the test cell layout (1-A) and its dimensions (1-B).

lateral surfaces of some samples were painted using varnish for further analysis using the 1D model of radon exhalation. Other samples were used in their original state for further analysis based on the 3D model of diffusion and exhalation.

To simulate the dwelling, the concrete test cells were built in the form of a cube with massive walls and hollow interior using CPIIZ-32 cement, common sand, and zero crushed stones. The manufacturing process was identical to that described earlier [9]. General details of the test cell can be seen in Fig. 1, which shows a layout of the test cell and its dimensions.

\section{Gamma spectrometry}

Initially, powdered samples of concrete and cement mortar were stored in Eckert borosilicate glass containers for 40 days, to achieve secular equilibrium between ${ }^{226} \mathrm{Ra}$ and its decay products. After that, using the installations of the Center of Nuclear Technology Development (CDTN/CNEN, Brazil), the samples were submitted to gamma spectrometry analysis. These measurements were performed using a gamma spectroscopy system (Canberra) [12] with hyperpure germanium (HPGe) semiconductor detector, with high efficiency (15\%) and resolution, installed inside the lead shield chamber. The analysis was performed using the gamma transitions of ${ }^{214} \mathrm{~Pb}$, ${ }^{214} \mathrm{Bi},{ }^{212} \mathrm{~Pb},{ }^{212} \mathrm{Bi},{ }^{228} \mathrm{Ac}$, and ${ }^{40} \mathrm{~K}$ to obtain the activity of ${ }^{226} \mathrm{Ra},{ }^{232} \mathrm{Th}$, and ${ }^{40} \mathrm{~K}$ in the studied materials. Consequently, the obtained results were used to evaluate the values of the radium equivalent activity $\left(\mathrm{Ra}_{e q}\right)$, the alpha hazard index $\left(I_{\alpha}\right)$, and the gamma hazard index $\left(I_{\gamma}\right)$ following standard recommendations [13-15]:

$$
\mathrm{Ra}_{e q}=A_{\mathrm{Ra}}+1.43 * A_{\mathrm{Th}}+0.077 * A_{\mathrm{K}}
$$




$$
\begin{gathered}
\text { (2) } I_{\alpha}=\frac{A_{\mathrm{Ra}}}{200 \mathrm{~Bq} \cdot \mathrm{kg}^{-1}} \\
\text { (3) } I_{\gamma}=\frac{A_{\mathrm{Ra}}}{300 \mathrm{~Bq} \cdot \mathrm{kg}^{-1}}+\frac{A_{\mathrm{Th}}}{200 \mathrm{~Bq} \cdot \mathrm{kg}^{-1}}+\frac{A_{\mathrm{K}}}{3000 \mathrm{~Bq} \cdot \mathrm{kg}^{-1}}
\end{gathered}
$$

where $A_{\mathrm{Ra}}, A_{\mathrm{Th}}$, and $A_{\mathrm{K}}$ are the measured values of specific activities of ${ }^{226} \mathrm{Ra},{ }^{232} \mathrm{Th}$, and ${ }^{40} \mathrm{~K}$, respectively.

From the radon concentration data obtained by the AlphaGuard (Saphymo GmbH) detector, it was possible to verify the radiological impact of the building materials by calculations of the emanation coefficient $(f)$. This coefficient could be defined as the ratio between the radon activity concentration released $\left(A_{\mathrm{Rn}}\right)$ into the air from the building material and the radium activity concentration inside $\left(A_{\mathrm{Ra}}\right)$ the building material. Therefore, this relationship can be represented by the following equation [16]:

$$
f=\frac{A_{\mathrm{Rn}}}{A_{\mathrm{Ra}}}
$$

Usually, the emanation coefficient $f$ varies from 1 to 0.3 , depending on the type of the building material, its density, porosity, particle size and shape, moisture content, temperature, atmospheric pressure, and other physical factors [17].

\section{Measurements of radon exhalation rate}

Among the factors that influence the exhalation rate of radon, the following factors need to be mentioned: the amount of water present in the building material, its porosity, grain size, temperature, atmospheric pressure, material sample geometry, and so on [18]. One of the possible ways to measure the rate of exhalation from the material sample is by the continuous monitoring of the radon activity in air as a function of time, according to Eq. (5) [7, 19]. To do this, the radon concentration has to be monitored in a closed environment, e.g., in a chamber or container.

$$
C(t)=C_{i} \cdot e^{-\left(\frac{\ln (2)}{T_{1 / 2}}\right) \cdot t}+\frac{E \cdot T_{1 / 2}}{V \cdot \ln 2} \cdot\left(1-e^{-\left(\frac{\ln (2)}{T_{1 / 2}}\right) \cdot t}\right)
$$

where $C$ is the concentration of ${ }^{222} \mathrm{Rn}\left[\mathrm{Bq} / \mathrm{m}^{3}\right], C_{i}$ is the initial concentration of ${ }^{222} \mathrm{Rn}\left[\mathrm{Bq} / \mathrm{m}^{3}\right], T_{1 / 2}$ is the half-life of ${ }^{222} \mathrm{Rn}$ of 3.8 days (91.2 hours), $t$ is the time [h], $E$ is the exhalation rate of ${ }^{222} \mathrm{Rn}[\mathrm{Bq} / \mathrm{h}]$, and $V$ is the total free volume for air circulation. The first term of the sum is related to the decay of the ${ }^{222} \mathrm{Rn}$ initially present in the system, while the second term refers to the exponential growth of ${ }^{222} \mathrm{Rn}$ released by the material sample until it reaches equilibrium. Evidently, when equilibrium is reached, the higher the exhalation rate, the bigger is the radon activity concentration in the indoor environment.

Short (48 hours) and long (12 days) measurements of radon exhalation rate were performed with four concrete samples and four cement mortar samples. The 3D model measurements were performed with samples in their original state. In the case of
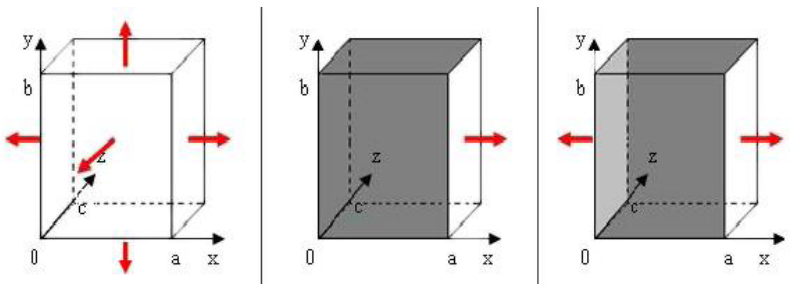

Fig. 2. Schematic diagrams of the three-dimensional and one-dimensional models of radon exhalation.

the $1 \mathrm{D}$ model, all surfaces of the material samples were painted with impermeable varnish, except the circular base area, through which radon gas can be released into the external atmosphere, as shown in Fig. 2. It is important to emphasize that, initially, this work focused on the 1D model as it is considered more accurate to describe the exhalation of radon from the walls, ceiling, and the floor of the dwelling.

The experimental arrangement consisted of the AlphaGuard professional radon monitor, glass jar with material samples, rotameter, glass container, air pump (AlphaPump), filters, and Tygon hoses connected in close circuit (Fig. 3). For the background measurements without material samples, the AlphaPump was adjusted to operate with a flow rate of $0.5 \mathrm{~L} / \mathrm{min}$ and the AlphaGuard was set to work in the $1 \mathrm{~min} /$ flow mode. Background measurements were performed over a period of 1 hour.

Short-term measurements of radon exhalation rate over a period of 48 hours were performed using four samples of the study materials installed inside a glass jar. AlphaGuard was operated in $1 \mathrm{~min} / \mathrm{flow}$ mode with the AlphaPump running at a rate of $0.5 \mathrm{~L} / \mathrm{min}$. Each measurement was repeated four times for every type of studied material. Long-term measurements were performed over a period of 12 days using similar parameters of AlphaGuard and AlphaPump operation and background control, but these measurements were performed only one time using four samples of each studied material.

To establish the relation between the radium present in the studied samples of building materials and the radon released into the atmosphere, three

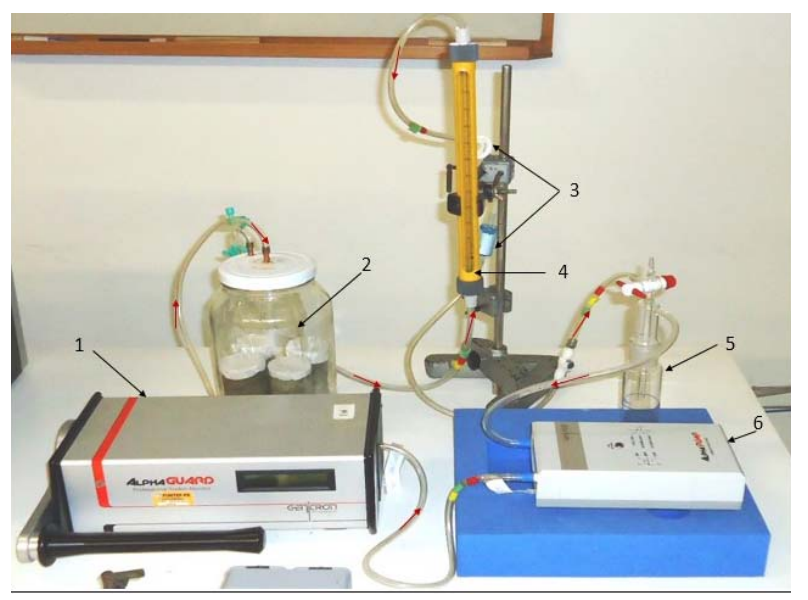

Fig. 3. Measurement of radon concentrations with AlphaGuard detector. 1 - AlphaGuard detector, 2 - samples within glass jar, 3 - filters, 4 - rotameter, 5 - glass container, 6 - air pump (AlphaPump). 
samples of concrete and cement mortar were stored in one sealed glass jar for 40 days to reach secular equilibrium of ${ }^{222} \mathrm{Rn}$ and ${ }^{226} \mathrm{Ra}$ isotopes. Measurements of radon activity were performed individually for each type of building material using the experimental setup described earlier and shown in Fig. 3. The measurements consist of three steps: the first is AlphaGuard ventilation with the aim to reduce the background and to ensure that intrinsic contamination of the equipment is as low as possible. In the next step, the background is measured for 1 hour using an empty and decontaminated glass jar. The third step consists of the measurement of radon activity in the atmosphere of glass containers with three samples of the studied building materials using AlphaGuard over a period of 2 hours. During the second and third steps, the AlphaGuard is operated in $1 \mathrm{~min} /$ flow mode, with the AlphaPump running at a rate of $0.5 \mathrm{~L} / \mathrm{min}$.

\section{Measurement of indoor radon concentration}

The contribution of radon exhalation from the construction materials to the air of the indoor environment was evaluated by installing 10 diffusion chambers with CR-39 detectors inside the test cell, where they remained for 21 days. The internal volume of $7.1 \mathrm{~cm}^{3}$ of the diffusion chamber was protected by a hollow cap with an installed glass microfiber filter GF52/C to restrain the entrance of dust and aerosols (Fig. 4).

During the measurements, the test cell remained in a well-ventilated room on the third floor of the university building (UTFPR) in order to exclude the possible contribution of radon from the soil and to obtain more accurate data associated with the concrete walls of the test cell. The background was controlled using three control detectors, which were installed in the external environment of a similar laboratory on the same floor. Among the seven detectors installed inside the test cell, three were placed at the bottom of the cell's internal cavity, two were placed in the middle, and the last two were installed at the top - near the concrete cap of the interior volume. The final results concerning indoor radon activity were calculated using the weighted average of results from all seven detectors installed in the test cell.

In the case of CR-39 detectors, the chemical attack and alpha particle track development were performed using 6.25 M sodium hydroxide $(\mathrm{NaOH})$ solution and ethanol $(2 \%)$ for 14 hours at $70^{\circ} \mathrm{C}$. The alpha particle tracks were identified and counted manually using an optical microscope with a magnification of $100 \times$ and a glass overlay mask, which permitted the identification of a $1 \mathrm{~cm}^{2}$ surface area of the CR-39. The calibration of CR-39 films was conducted in collaboration with the Center for Development of Nuclear Technology (CDTN/CNEN) at the facility of the National Institute of Radiological Sciences (NIRS) in Japan, where 30 diffusion chambers with mounted CR-39 detectors were exposed within a controlled environmental storage room in an atmosphere with varied concentrations of ${ }^{222} \mathrm{Rn}$. Next, the exposed detectors were returned to the laboratories of CDTN and UTFPR, where they were etched and read. The comparison between the radon activities used for calibration and the obtained number of alpha particle tracks, together with statistical errors, resulted in Eq. (6) [20].

$$
C=(405 \pm 30) \cdot n \quad\left[\mathrm{~Bq} \cdot \mathrm{cm}^{2} \cdot \mathrm{h} \cdot \mathrm{m}^{-3}\right]
$$

where $n$ represents the density of the counted alpha particle tracks per square centimeter and per hour of exposure of the CR-39 detector to the studied environment and $C$ is activity concentration of radon in becquerel per meter cubed $\left[\mathrm{Bq} / \mathrm{m}^{3}\right]$.

\section{Results, discussion, and conclusion}

\section{Results of gamma spectrometry analysis}

The results of gamma spectrometry analysis of concrete and cement mortar are shown in Table 1; the results of ${ }^{226} \mathrm{Ra},{ }^{232} \mathrm{Th}$, and ${ }^{40} \mathrm{~K}$ activity concentration, together with the calculated values of the radium equivalent activity $\left(\mathrm{Ra}_{e q}\right)$ and the gamma hazard index $\left(I_{\gamma}\right)$, are shown.

The results for $I_{\gamma}$ do not exceed the value of 0.5 recommended by the European Commission (1999)

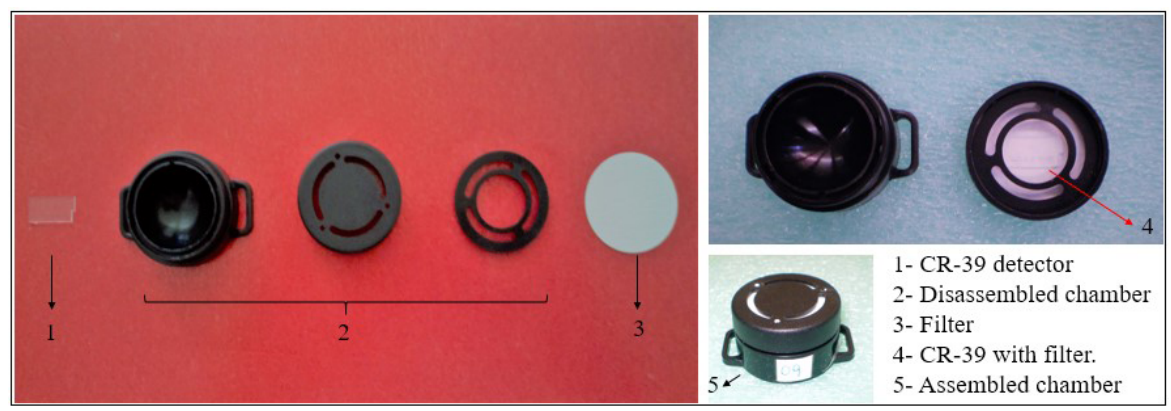

Fig. 4. Diffusion chamber and CR-39 detector.

Table 1. Obtained results of gamma spectrometry analysis and calculated values of hazard indexes $\operatorname{Ra}_{e q}$ and $I_{\gamma}$

\begin{tabular}{lccccc}
\hline \multicolumn{1}{c}{ Sample } & $\begin{array}{c}A_{\mathrm{Ra}} \\
{[\mathrm{Bq} / \mathrm{kg}]}\end{array}$ & $\begin{array}{c}A_{\mathrm{Th}} \\
{[\mathrm{Bq} / \mathrm{kg}]}\end{array}$ & $\begin{array}{c}A_{\mathrm{K}} \\
{[\mathrm{Bq} / \mathrm{kg}]}\end{array}$ & $I \gamma$ & $\begin{array}{c}\mathrm{Ra}_{e q} \\
{[\mathrm{~Bq} / \mathrm{kg}]}\end{array}$ \\
\hline Concrete & $13.8 \pm 0.2$ & $29.7 \pm 0.2$ & $434.5 \pm 3.5$ & $0.3395 \pm 0.0017$ & $89.8 \pm 0.4$ \\
Cement mortar & $12.6 \pm 0.2$ & $29.6 \pm 0.2$ & $361.8 \pm 3.5$ & $0.3106 \pm 0.0017$ & $82.8 \pm 0.4$ \\
\hline
\end{tabular}




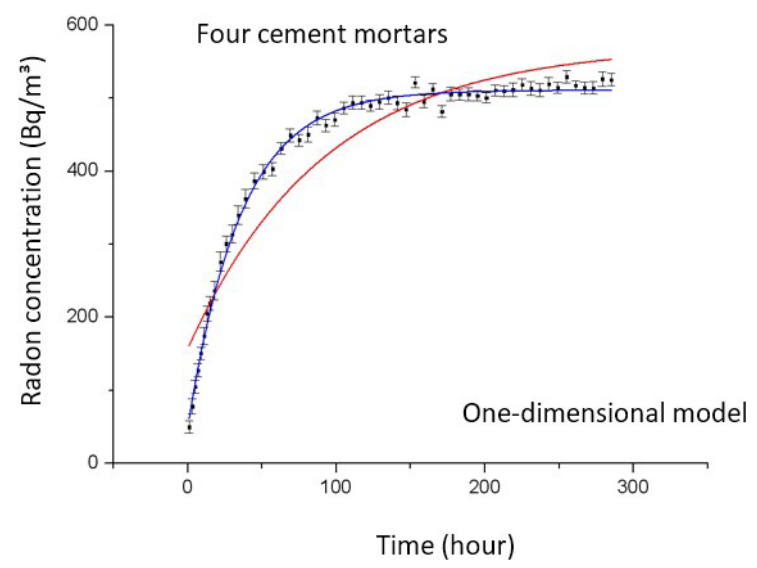

Fig. 5. Graphical comparison between the curves of the radon exhalation rates.

for an annual effective dose of $0.3 \mathrm{mSv} / \mathrm{year}$ [13]. It should be noted that both concrete and cement mortar samples presented radium equivalent activity $\left(\mathrm{Ra}_{e q}\right)$ below the maximum permissible value of $370 \mathrm{~Bq} / \mathrm{kg}$ [14], which corresponds to an annual effective dose of $1 \mathrm{mSv} /$ year, for the residents of simple family houses and apartments recommended by United Nations Scientific Committee on the Effects of Atomic Radiation (UNSCEAR) (2000) [15].

\section{Results of radon exhalation rate measurements}

The function represented by Eq. (5) was adjusted to the experimental data obtained by AlphaGuard

$$
6-\mathrm{A}
$$

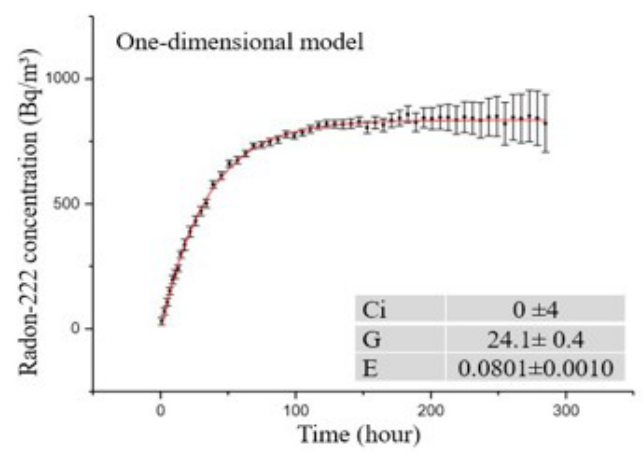

6-C

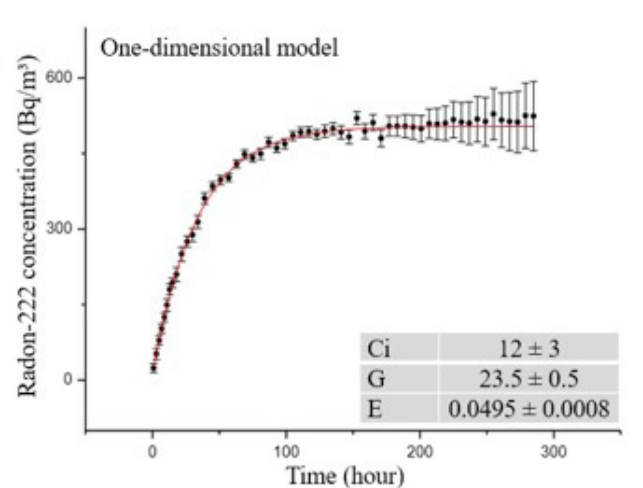

radon detector during exhalation rate measurements. The free volume $V$ of the experimental setup was estimated to be equal to $3.33 \times 10^{-3} \mathrm{~m}^{3}$. First, the decay rate used for the adjustment was that which considered the half-life of ${ }^{222} \mathrm{Rn}$ of 3.8 days (91.2 h), represented by the red curve (Fig. 5). It has to be noted that this curve does not agree with the experimental data and it shows that equilibrium (curve's plateau) should occur later than it was obtained. The same curve indicates that the increase in concentration should continue growing. This means that either the experimental setup had gas leakage or that the characteristic decay time (effective half-life described later) is not 3.8 days. This can occur due to the longer time that radon takes to be released from the material sample and be detected by the AlphaGuard. Hence, as no gas leakage was found in the measurement circuit, the second hypothesis was taken as the most appropriate.

As discussed in a previous paper [19], the solution to this problem is to substitute in Eq. (5) the half-life of radon $\left(T_{1 / 2}\right)$ by a new quantity, viz., "effective half-life" $G$ (Eq. (7)), which was used as the fitting parameter. The results of this fitting are shown in Fig. 5 by the blue curve. One can see that such an approach is more adequate to describe the experimental data. Moreover, if the fitting procedure provides a value for $G<91.2$ hours, it means that, on average, the radon takes some time to be released from the material sample in the atmosphere of the glass container.
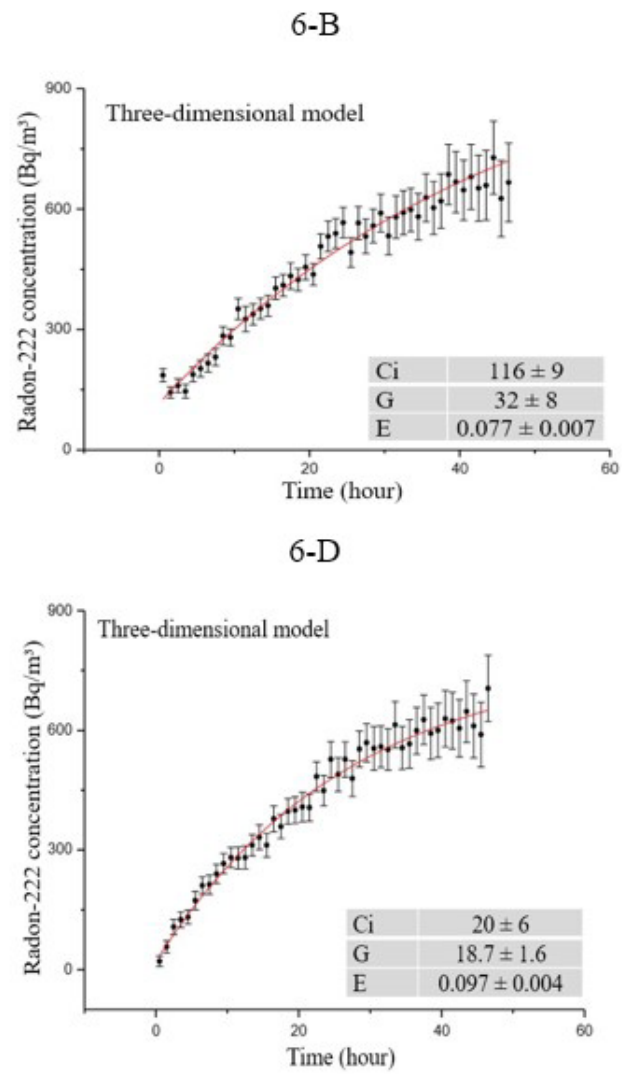

Fig. 6. Graph of ${ }^{222} \mathrm{Rn}$ concentration in the air exhaled from concrete (6-A and 6-B) and cement mortar (6-C and 6-D) samples as a function of time. The results of numerical analysis (fitting) using one-dimensional and three-dimensional models are shown as red line. 
Table 2. Mean values of exhalation rate fitting parameters

\begin{tabular}{lccrcccc}
\hline Sample & Model & $\begin{array}{c}\text { Measurement } \\
\text { time }\end{array}$ & $\begin{array}{c}C_{i} \\
{\left[\mathrm{~Bq} / \mathrm{m}^{3}\right]}\end{array}$ & \multicolumn{1}{c}{$\begin{array}{c}G \\
{[\mathrm{~h}]}\end{array}$} & $\begin{array}{c}E \\
{[\mathrm{~Bq} / \mathrm{h}]}\end{array}$ & $\begin{array}{c}E_{\text {mass }} \\
{[\mathrm{Bq} /(\mathrm{h} \cdot \mathrm{kg})]}\end{array}$ & $\begin{array}{c}E_{\text {area }} \\
{\left[\mathrm{Bq} /\left(\mathrm{h} \cdot \mathrm{m}^{2}\right)\right]}\end{array}$ \\
\hline \multirow{2}{*}{ Concrete } & 1D days & $0 \pm 4$ & $24.1 \pm 0.4$ & $0.0801 \pm 0.001$ & $0.1819 \pm 0.0023$ & $2.550 \pm 0.03$ \\
& & 48 hours & $49 \pm 4$ & $23.5 \pm 1.2$ & $0.0855 \pm 0.0019$ & $0.1960 \pm 0.004$ & $2.750 \pm 0.06$ \\
& 3D & 48 hours & $106 \pm 5$ & $20.0 \pm 1.5$ & $0.0900 \pm 0.004$ & $0.2060 \pm 0.008$ & $0.482 \pm 0.018$ \\
& & 12 days & $49 \pm 6$ & $22.0 \pm 0.5$ & $0.0870 \pm 0.0015$ & $0.1980 \pm 0.003$ & $0.461 \pm 0.008$ \\
Cement & 1D & 12 days & $12 \pm 3$ & $23.5 \pm 0.5$ & $0.0495 \pm 0.0008$ & $0.1125 \pm 0.0019$ & $1.580 \pm 0.03$ \\
mortar & \multirow{2}{*}{ 30 hours } & $30 \pm 3$ & $15.1 \pm 0.8$ & $0.0746 \pm 0.0020$ & $0.1720 \pm 0.005$ & $2.400 \pm 0.07$ \\
& & 48 hours & $28 \pm 4$ & $20.4 \pm 1.1$ & $0.0913 \pm 0.0023$ & $0 \pm 4$ & $0.481 \pm 0.012$ \\
& & 12 days & $88 \pm 8$ & $23.1 \pm 0.7$ & $0.0827 \pm 0.0021$ & $0.1880 \pm 0.005$ & $0.439 \pm 0.011$ \\
\hline
\end{tabular}

$$
C(t)=C_{i} \cdot e^{-\left(\frac{\ln (2)}{G}\right) \cdot t}+\frac{E \cdot G}{V \cdot \ln 2} \cdot\left(1-e^{-\left(\frac{\ln (2)}{G}\right) \cdot t}\right)
$$

From the experimental point of view, the effective half-life $G$ gives the information of how long, on average, the radon atoms take to be released from the sample, which could be termed the exhalation time $\left(T_{\text {exhalation }}\right)$, defined by $G=T_{1 / 2}-a \times T_{\text {exhalation, }}$ where $a$ is some numerical coefficient related to radon reabsorption by the material sample, back diffusion, and similar processes. The results obtained by such fitting can be seen in Fig. 6 , where $C_{i}$ is displayed in $\left[\mathrm{Bq} / \mathrm{m}^{3}\right], E$ in $[\mathrm{Bq} / \mathrm{h}]$, and $G$ in $[\mathrm{h}]$. It has to be noted that the comparison of the half-life of ${ }^{222} \mathrm{Rn}$ of 91.2 hours and the obtained value of the effective half-life $G$ of $18-32$ hours gives a rather elevated time of 22-24 hours of diffusion and exhalation of radon from the studied samples of building materials into the atmosphere of the glass container (see the explanations of Table 2).

The final results of the data fitting using the parameters of effective half-life $(G)$, the radon exhalation rate $(E)$, and radon exhalation rate per unit mass and per unit area $\left(E_{\text {mass }}\right.$ and $\left.E_{\text {area }}\right)$ are shown in Table 2. The values of the last two parameters were obtained considering the masses of the building material samples and their surfaces: in the case of the 3D exhalation model, the entire surface area of cylindrical samples was considered, and in the case of the 1D exhalation model, only the area of the circular base that was free for gas exhalation was considered, while the remainder of the cylindrical sample was painted using impermeable varnish.

In the case of long-term measurements, the exponential terms of Eq. (7) tend to zero, leaving the constant term $(E \times G) /(V \times \ln 2)$, which depends on $E$. During the 12-day measurements, such a steady state was established after $\sim 150$ hours. In this way, long-term measurements should be considered more appropriate for the determination of exhalation rate than short-term measurements. It was observed that for cement mortar, radon takes about 21.1 \pm 2.4 hours (applying the 1D diffusion model) and $22.3 \pm$ 1.7 hours (in the case of the $3 \mathrm{D}$ model) to be released from the building material. For concrete, the evaluated exhalation time of radon was about 24.0 \pm 2.6 hours and $21.8 \pm 2.1 \mathrm{~h}$ using the $1 \mathrm{D}$ and $3 \mathrm{D}$ models for radon exhalation, respectively. It could be concluded that the performed measurements and the analysis of experimental data do not permit observ-
Table 3. Results of radon activity concentration $\left[\mathrm{Bq} / \mathrm{m}^{3}\right]$ in the concrete and cement mortar

\begin{tabular}{lcc}
\hline \multicolumn{1}{c}{ Material } & System + sample & Sample \\
\hline Concrete & $2993 \pm 57$ & $2956 \pm 57$ \\
Cement mortar & $2188 \pm 39$ & $2152 \pm 39$ \\
\hline
\end{tabular}

ing any difference in the exhalation time between the $1 \mathrm{D}$ and 3D models for both materials.

Finally, Table 3 shows the ${ }^{222} \mathrm{Rn}$ activity concentration results obtained in the measurements with the material samples that were maintained in sealed glass containers for 40 days to reach secular equilibrium of ${ }^{222} \mathrm{Rn}$ and ${ }^{226} \mathrm{Ra}$ isotopes.

These values were used to determine the ${ }^{226} \mathrm{Ra}$ activity present in the studied samples and for further calculations of the emanation coefficient using its definition (Eq. (4)), the values for which were found to be $38.2 \% \pm 1.0 \%$ for concrete and $31.7 \%$ $\pm 0.8 \%$ for cement mortar. Usually the values of the emanation coefficient for common building materials vary between 1\% and 30\% [17].

Results of measurements of radon activity in the air within the internal cavity of the test cell

The obtained value of radon activity concentration in the air of the internal cavity of the test cell was found to be $1680 \pm 140 \mathrm{~Bq} / \mathrm{m}^{3}$. Evidently, this elevated value was obtained due to the area/volume ratio of $0.3 \mathrm{~cm}^{-1}$ for that internal chamber of test cell. However, the area/volume ratio of a dwelling is much smaller. Hence, the value of radon activity concentration obtained in the test cell was extrapolated to an internal environment of approximate dimensions of $3 \times 3 \times 3 \mathrm{~m}^{3}$, with area/volume ratio of $0.02 \mathrm{~cm}^{-1}$. This extrapolated value of radon activity concentration in the air of such a hypothetical environment was found to be equal to $112 \pm 9 \mathrm{~Bq} / \mathrm{m}^{3}$. Evidently, such result could be considered as valid only in the case of equal thickness of concrete walls and the absence of ventilation as maintained in the measurements with the test cell. Anyway, considering that the upper limit for radon activity in the air of dwellings is $300 \mathrm{~Bq} / \mathrm{m}^{3}$ [21] and considering that the obtained value of $112 \mathrm{~Bq} / \mathrm{m}^{3}$ is related only to the radon released by the concrete walls, it can be concluded that the observed possible contribution of concrete and cement is rather significant and requires further investigation. 


\section{Conclusions}

The way in which concrete and mortar concrete are manufactured ensured similarity with the materials commonly used in the construction of commercial buildings and dwellings. The radon exhalation rate was determined by monitoring the ${ }^{222} \mathrm{Rn}$ activity in a closed system (closed chamber method) during long- and short-term measurements. The values of the exhalation rate were calculated by fitting the experimental data obtained using the theoretical approach, where we used $1 \mathrm{D}$ and 3D models of gas exhalation from cylindrical sample body.

The obtained results of radon activity in the air of the concrete test cell do not represent the reality of a human dwelling environment due to the difference between the area/volume factors. In this way, the obtained extrapolated concentration value for a human dwelling environment was 15 times lower, namely, $112 \pm 9 \mathrm{~Bq} / \mathrm{m}^{3}$. Even so, this value is significant, since it is relative only to the contribution of concrete walls. Hence, it is important to reduce the radon exposure from the building materials using mitigation approaches and to continue investigations concerning radon levels in living and working environments and the use of different kinds of building materials.

The performed study intends to contribute to the development of mitigation proposals for the decrease of possible radon concentration to levels below the limits established by international agencies, such as the UNSCEAR [2-4], the International Commission on Radiological Protection (ICRP) [22], and the US Environmental Protection Agency (US EPA) [23].

Acknowledgments. The authors are very thankful to the Federal University of Technology - Paraná (UTFPR), CNPq, and CAPES for financial support of this work, as well as to colleagues from the CDTN/CNEN for their help and support in measurements and productive discussion of the obtained results.

\section{References}

1. National Cancer Institute. (2013). What you need to know about lung cancer. NCI Publication. Retrieved February 1, 2013, from http://cancernet.nci.nih.gov/ wyntk pubs/lung.htn

2. United Nations Scientific Committee on the Effects of Atomic Radiation. (1993). Sources and effects of ionizing radiation, annex $A$. UNSCEAR Report to the United Nations General Assembly.

3. United Nations Scientific Committee on the Effects of Atomic Radiation. (2008). Sources and effects of ionizing radiation, annex $B$. I. UNSCEAR Report to the United Nations General Assembly.

4. United Nations Scientific Committee on the Effects of Atomic Radiation. (2006). Sources and effects of ionizing radiation, annex E. II. UNSCEAR Report to the United Nations General Assembly.

5. United States Environmental Protection Agency. (2001). Building radon out. A step-by-step guide on how to build radon resistant homes. US EPA, Office of Air and Radiation. Available from https://www. epa.gov/sites/production/files/2014-08/documents/ buildradonout.pdf.

6. Zhang, L., Lei, X., Guo, Q., Wang, S., Ma, X., \& Shi, Z. (2012). Accurate measurements of radon exhalation rate of building materials using the closed chamber method. J. Radiol. Prot., 32(3), 315-323. DOI: $10.1088 / 0952-4746 / 32 / 3 / 315$.

7. Tuccimei, P., Castelluccio, M., Soligo, M., \& Moroni, M. (2009). Radon exhalation rates of building materials: Experimental, analytical protocol and classification criteria. (2009). In D. N. Cornejo, J. L. Haro (Eds.). Building materials: Properties, performance and applications (pp. 1-15). New York: Nova Science Publishers.

8. Bruno, R. C. (2012). Sources of indoor radon in houses: A review. J. Air Pollut. Control Assoc., 33(2), 105-109. DOI: 10.1080/00022470.1983.10465550.

9. Perna, A. F. N. (2016). Taxa de exalação de radônio-222 de concreto e argamassa de cimento usados na construção civil. Master dissertation, Universidade Tecnológica Federal do Paraná. Curitiba, Brazil.

10. Associação Brasileira de Normas Técnicas. (2012). Concreto - procedimento para moldagem e cura de corpos-de-prova. NBR NM 67. Brazil.

11. Associação Brasileira de Normas Técnicas. (1996). Cimento Portland - Determinação da resistência à compressão. NBR 7215. Brazil.

12. CANBERRA. (2015). Measurement solution for nuclear safety, security and the environment. Retrieved January 10, 2016, from http://www.canberra. com/products/detectors/germanium-detectors.asp.

13. European Commission. (1999). Radiological protection principles concerning the natural radioactivity of building materials, $n$. 112. Directorate - General Environment, Nuclear Safety and Civil Protection.

14. Beretka, J., \& Mathew, P. J. (1985). Natural radioactivity of Australian building materials, industrial wastes and by-products. Health Phys., 48, 87-95.

15. United Nations Scientific Committee on the Effects of Atomic Radiation. (2000). Sources and effects of ionizing radiation, annex $B$. I. UNSCEAR Report to the United Nations General Assembly.

16. Kovler, K., Perevalov, A., Stener, V., \& Metzger, L. A. (2005). Radon exhalation of cementitious materials made with coal fly ash: Part 1 - scientific background and testing of the cement and fly ash emanation. J. Environ. Radioact., 82, 321-334. http://dx.doi. org/10.1016/j.jenvrad.2005.02.004.

17. Bikit, I., Mrda, D., Grujic, S., \& Kozmidis-luburic, U. (2011). Granulation effects on the radon emanation rate. Radiat. Prot. Dosim., 145(2/3), 182-188. https://doi.org/10.1093/rpd/ncr055.

18. Hassan, N. M., Hosoda, M., Ishikawa, T., Sorimachi, A., Sahoo, S. K., Tokonami, S., \& Fukushi, M. (2009). Radon migration process and its influence factors: review. Jpn. J. Health Phys., 44(2), 218-231.

19. Petropoulos, N. P., Anagnostakis, M. J., \& Simopoulos, S. E. (2001). Building materials radon exhalation rate: ERRICCA intercomparison exercise results. Sci. Total Environ., 272(1/3), 109-118.

20. Corrêa, J. N. (2011). Avaliação dos Niveis de Concentração de Radônio em Ambientes e Águas de Poços 
no Estado do Paraná. Doctoral dissertation, Universidade Tecnológica Federal do Paraná. Curitiba, Brazil.

21. Comissão Nacional de Energia Nuclear. Ministério da Ciência e Tecnologia. (2005). Níveis de intervenção e de ação para exposição crônica. Posição Regulatória 3.01/007. Rio de Janeiro, Brasil.

22. International Commission on Radiological Protection. (2014). Radiological protection against radon exposure. (ICRP Publication 126). Ann. ICRP 43. http:// www.icrp.org/publication.asp?id=ICRP Publication.
23. United States Environmental Protection Agency. (2016). A Citizen's guide to radon: The guide to protecting yourself and your family form radon. (EPA 402/K-12/002/2016 www.epa.gov./radon). Available from https://www.epa.gov/sites/production/ files/2016-12/documents/2016_a_citizens_guide_ to_radon.pdf. 